\title{
Histopathology of the chronic soft-shell syndrome in the tiger prawn Penaeus monodon*
}

\author{
M. C. L. Baticados, R. M. Coloso, R. C. Duremdez \\ Aquaculture Department, Southeast Asian Fisheries Development Center, Tigbauan, Iloilo, Philippines
}

\begin{abstract}
One of the disease problems that affect the production of tiger prawn Penaeus monadon Fabricius in brackish-water ponds is the chronic soft-shell syndrome, a condition in which the prawn. shell is persistently soft for several weeks. To determine the extent of damage in affected prawns, the histopathology of this syndrome was studied using light microscopy, transmission and scanning electron microscopy, and histochemical determination of calcium. Light microscopic studies of the exoskeleton of soft and normal hard-shelled prawns showed several distinct layers: an outer epicuticle, a thick exocuticle and a thinner endocuticle overlying the epidermis. The cuticular layers of the soft shell often had a rough or wrinkled surface and were usually disrupted and separated from the epidermis while those of the hard shell were generally intact and attached to the epidermis. The exocuticle and endocuticle of the hard shell were considerably thicker than those of the soft shell. Ultrastructural observations revealed the presence of a very thin membranous layer under the endocuticle. Tegumental ducts and pore canals traversed the 4 cuticular layers and were distinctly observed as pore openings on the epicuticle surface. The epicuticle had a bilaminar and non-lamellate structure. The exocuticle had more widely-spaced lamellae consisting of fibers arranged in a more compact pattern than in the endocuticle. Histochemical determination of calcium was done in exoskeleton and hepatopancreas of soft- and hard-shelled prawns. The hepatopancreas of soft-shelled prawn stained more intensely for calcium than that of the hard-shelled one. There was no great difference in calcium content of hard and soft shell, although the former stained slightly more intensely. Histopathological changes in the hepatopancreas of soft-shelled prawns were also observed.
\end{abstract}

\section{INTRODUCTION}

The chronic soft-shell syndrome in the giant tiger prawn Penaeus monodon Fabricius is a significant factor in decreased production of some brackish-water ponds in the Philippines. This syndrome was found to result from nutritional deficiency, exposure to a chemical pesticide, poor pond soil and water conditions, and was highly correlated with some management practices in the pond (Baticados et al. 1986).

Previous chemical studies indicated that exoskeleton and hepatopancreas play the more important roles in prawn-shell hardening, vis-a-vis the hemolymph and residual tissues (Baticados et al. 1986). Apart from the fact that abnormal soft-shelled prawns have shells that are persistently soft or papery for several weeks, nothing was known about the extent of damage in these prawn tissues. Moreover, in spite of the many reports on the structure of the crustacean cuticle (Travis

\footnotetext{
- SEAFDEC Contribution No. 219
}

1955, 1957, 1960, 1963, Travis \& Friberg 1963, Dall 1965, Yano 1975, Dillaman \& Roer 1980, Johnson 1980, Roer \& Dillaman 1984), information on Penaeus monodon was lacking. To bridge these gaps, the histopathology of the chronic soft-shell syndrome was examined. We studied histological changes in the abnormal soft shell and hepatopancreas, and determined the histochemical levels of calcium in these tissues with reference to normal prawn tissues.

\section{MATERIALS AND METHODS}

Source of samples. Hard- and soft-shelled Penaeus monodon ( 11.2 to $52.3 \mathrm{~g}$ ) were collected from various prawn ponds in Panay Island during field surveys. The samples were graded according to a tentative grading system based primarily on the quality of the exoskeleton. Soft-shelled prawns, graded G1 and G2, were softbodied, weak, and had shells that were very soft to 


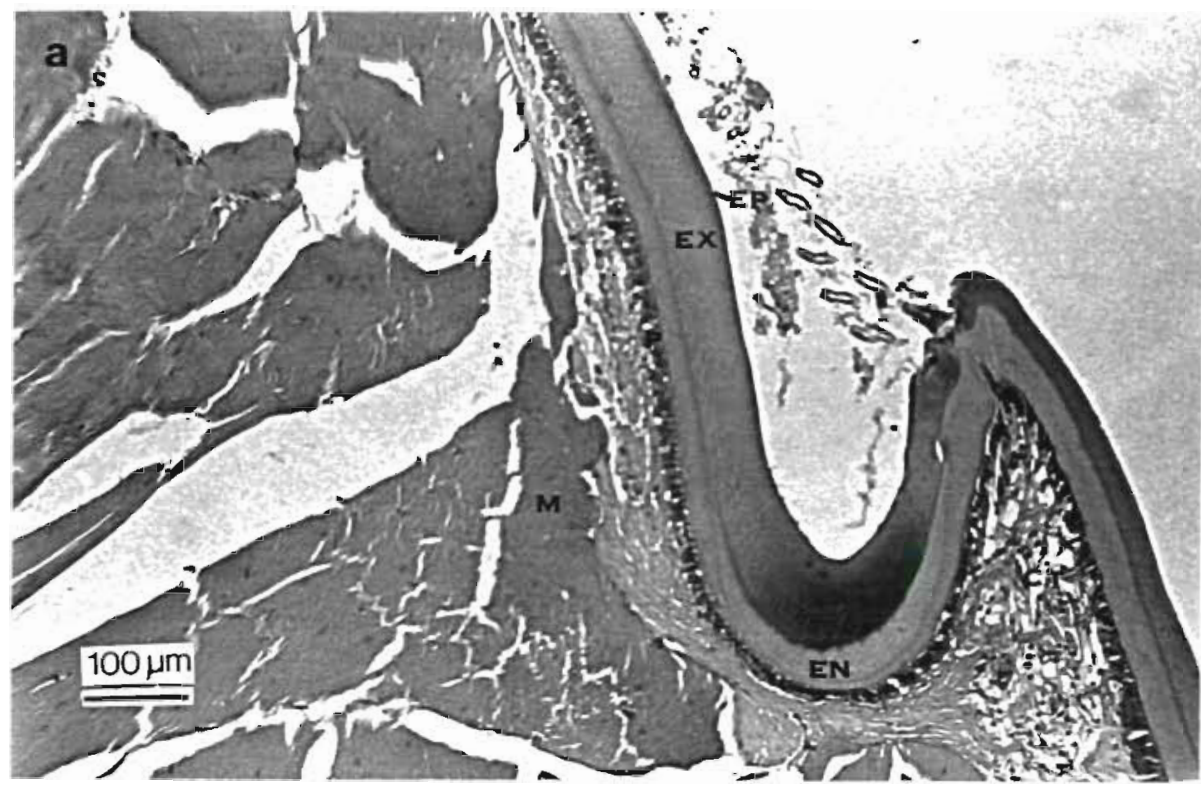

Fig. 1. Penaeus monodon. Exoskele ton and adjacent tissues of normal hard-shelled prawn showing the different layers. Cross-section. EP epicuticle; EX: exocuticle; EN: endocuticle; P: epidermis; CT: connective tissue; $M$ : muscle tissues Mallory's triple stain. (a) $100 \times$ (b) $400 x$ papery, loose, dark, often wrinkled, with lesions/blisters and ecto-commensals. Hard-shelled prawns, graded G3 and G4, were firm-bodied, active and had shells that were very slightly papery to very hard, smooth and distinctly banded (Baticados et al. 1986). Newly molted prawns, on the other hand, had firm bodies and shells that were soft, thin, clean, smooth, distinctly banded, and hardened within 1 to $2 \mathrm{~d}$. The samples used for histological and histochemical analysis were all in the intermolt stage. The samples were taken from stocks that were 1 to 11 mo old and cultured at densities of 400 to 12000 ind. per hectare, salinities of 13 to $40 \mathrm{ppt}$, temperatures of 24.5 to $34^{\circ} \mathrm{C}$, water $\mathrm{pH}$ of 6.5 to 9.25 and soil $\mathrm{pH}$ of 4.77 to 7.85 . Details of quantifiable water and soil survey data in the ponds were given by Baticados et al. (1986). As observed from the sources of these samples, prawns given adequate and good quality food/feed, i.e. natural food (plankton or aquatic plant Ruppia maritima) and/or a sufficient supply of supplementary feeds (mussel, trash fish or crustacean pellets), were generally hard-shelled, while those getting insufficient or low-quality food were generally soft-shelled (Baticados et al. 1986).

Histological methods. Light microscopy. The second abdominal segments were cut from hard- and softshelled prawns, fixed in $10 \%$ buffered formalin, washed and dehydrated through a graded series of alcohols, cleared in chloroform, infiltrated with and embedded in paraffin and sectioned at 5 to $6 \mu \mathrm{m}$ thick. The sections were affixed to slides and stained with Mallory's triple stain and haematoxylin-eosin using standard methods (Humason 1972). The slides were examined and photomicrographs were taken with an Olympus Vanox research microscope. Measurements of the exoskeleton

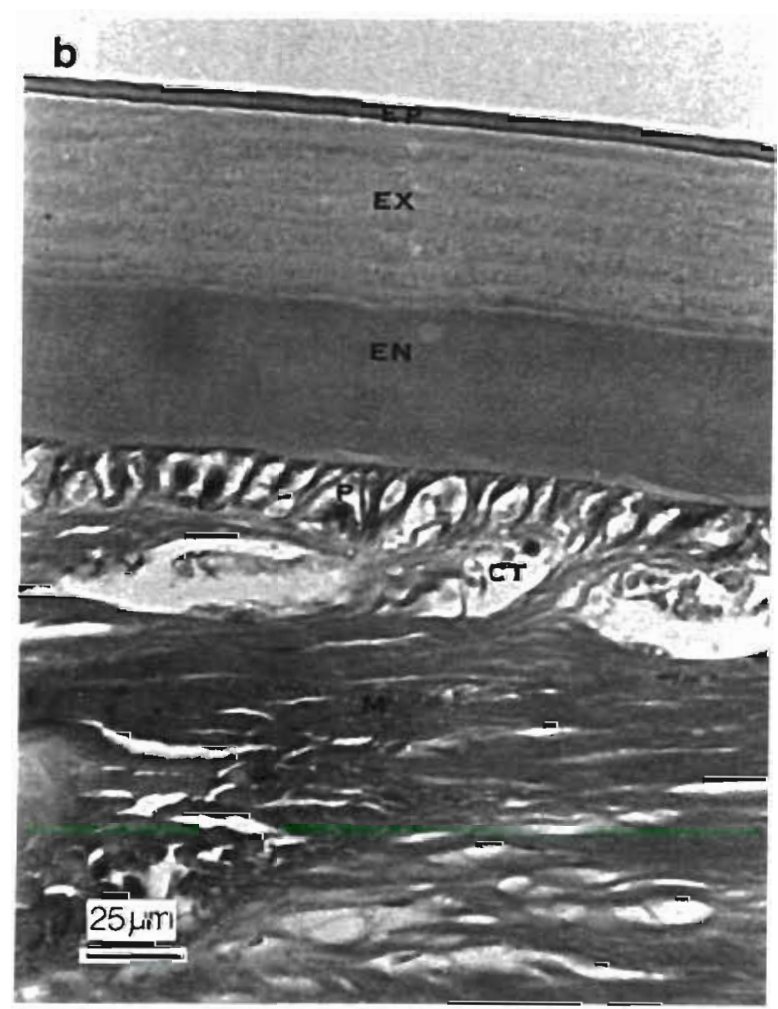

layers were made with an eyepiece micrometer. Means were tested for significance of differences using Student's t-test. The terminologies used by Travis (1963) and Johnson (1980) were applied in this study 
Electron microscopy. For transmission electron microscopy, small pieces ( 1 to $2 \mathrm{~mm}^{2}$ ) of exoskeleton were cut from hard- and soft-shelled prawns, fixed in $2.5 \%$ glutaraldehyde in phosphate buffer, washed, postfixed in $1 \%$ osmium oxide, washed, dehydrated through a graded series of acetones, infiltrated with and embedded in araldite and cut at 50 to $100 \mathrm{~nm}$ with glass knives on an ultrotome. Sections were placed in copper grids and stained with uranyl acetate and lead citrate. Electron micrographs were obtained using a JEOL $100 \mathrm{U}$ transmission electron microscope.

For scanning electron microscopy, similar small pieces of the exoskeleton were processed up to dehydration through a graded series of acetones, mounted on brass stubs with a double-stick cellophane tape, and quickly air-dried. The samples were partially painted with silver, coated with gold via an ion sputtering device and examined at 12 to $13 \mathrm{kV}$ with a JEOL JSM-35C scanning electron microscope.

Electron probe microanalysis. Small pieces of the exoskeleton similarly prepared for SEM were mounted on metal stubs using a dotite electro-conductive paint and carbon-coated for qualitative point analyses. As a representative layer, the exocuticle was used to determine if there is any difference in the elemental composition of hard and soft shell. The electron beam of the Shimadzu-Arl EMX-SM 7 Electron Probe Micro-Analyzer was directed to the exocuticle in cross-sections of the prawn exoskeleton samples. Only 2 analyzing crystals were used, viz. LiF and ADP, which could detect elements from $K$ (atomic no. 19) to U (atomic no. 92).

Histochemical determination of calcium. Hepatopancreas and second abdominal segment were dis- sected from hard- and soft-shelled prawns, fixed overnight in $10 \%$ buffered formalin, processed, and stained with Alizarin Red S for calcium (Johnson 1980) and haematoxylin-eosin using standard methods (Humason 1972). The sections were examined under an Olympus Vanox research microscope. Calcium-containing tissues stain orange to red.

\section{RESULTS}

\section{Histopathology of the exoskeleton}

Light microscopic observations showed that the cuticular layers of the hard shell are intact and attached to the epidermis (Fig. 1). There is an outermost epicuticle, a thick exocuticle which appears to be lamellated, a relatively thinner endocuticle, overlying the innermost epidermis. The connective tissues next to the epidermal layer may be compact or loose and are directly in contact
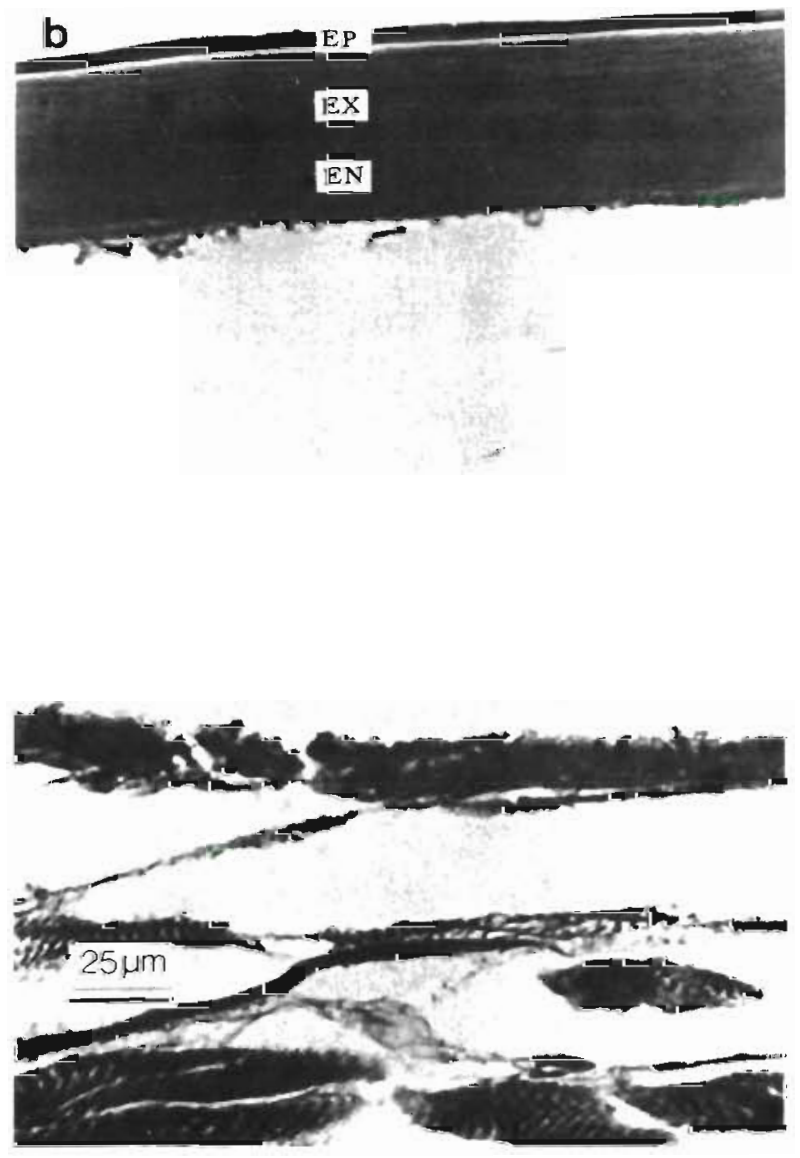

Fig. 2. Penaeus monodon. Exoskeleton and adjacent tissues of a soft-shelled prawn showing a rough or wrinkled surface. Layers are often disrupted and separated from epidermis $(\mathrm{P})$ Cross-section. EP: epicuticle; EX: exocuticle; EN: endocuticle; CT. connective tissues; $M$ : muscle tissues. Mallory's triple stain. (a) $100 x_{\text {; }}$ (b) $400 x$ 


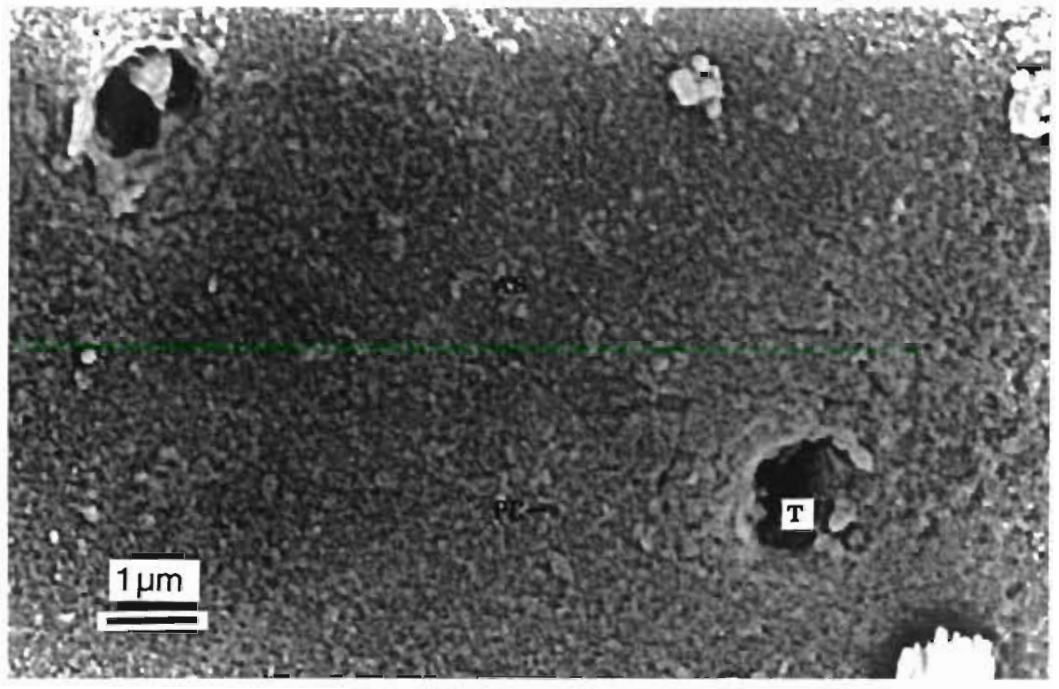

Fig. 3. Penaeus monodon. Surface of epicuticle of normal hard-shelled prawn showing little or fine amorphous substance (AS). PC: pore canal spaces; $T$. tegumental gland pore. SEM; $22000 \times$

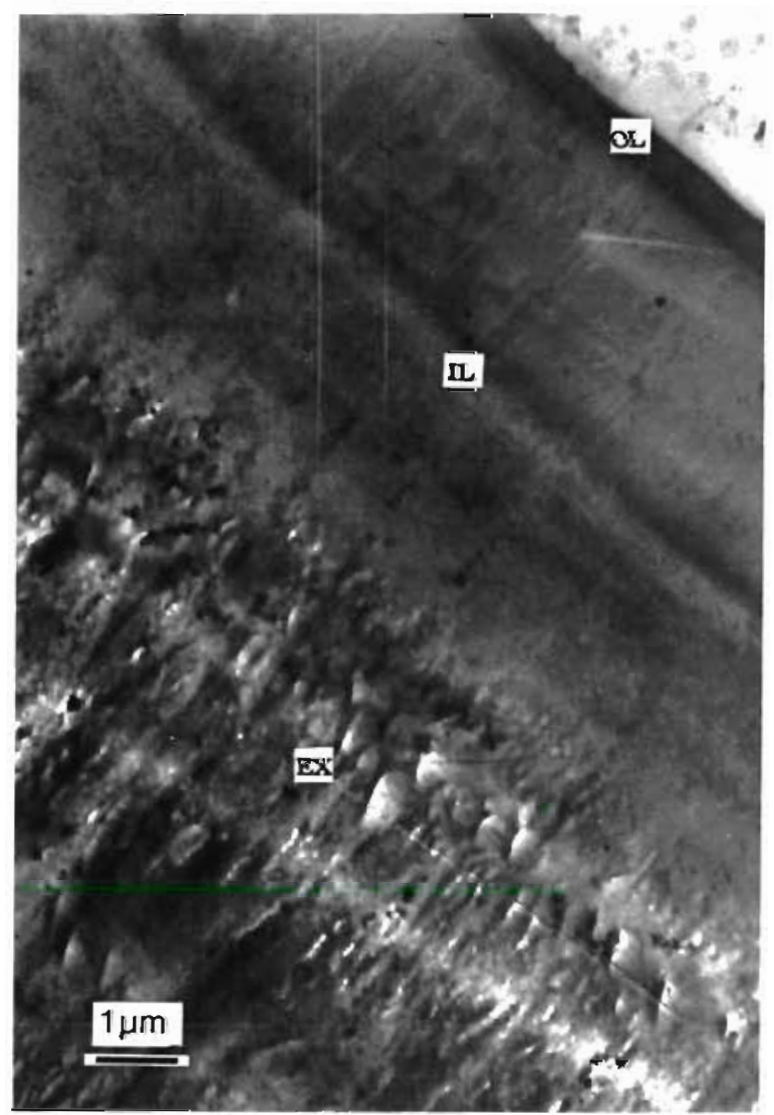

Fig. 4. Penaeus monodon. Cross-section of epicuticle of hardshelled prawn showing the thin, electron-dense outer layer (OL) and the thicker inner layer (IL). Marks perpendicular to cuticle surface are due to sectioning. EX: exocuticle. TEM; $8000 x$ with the muscle tissues on the other side. The exoskeleton reveals a distinct laminate and radial pattern.

On the other hand, the cuticular layers of the soft shell often showed a rough or wrinkled surface and are usually disrupted and separated from the epidermis (Fig. 2). Likewise, the cuticular layers are quite distinct but in some cases, the epidermal and connective tissues are easily destroyed during processing or the major cuticular layers (i.e. exocuticle and endocuticle) easily separate from each other.

Comparison of the thickness of epicuticle, exocuticle and endocuticle of hard and soft shells showed that exocuticle and endocuticle of the hard shell are significantly thicker than those of the soft shell (Table 1).

Table 1 Penaeus monodon. Thickness of exoskeleton layers shown as means, (in $\mu \mathrm{m}$ ) and as percentage of total exoskeleton thickness

\begin{tabular}{lccc}
\hline Shell character & Epicuticle & Exocuticle & Endocuticle \\
\hline Hard & $5.3(5.06)$ & $60.0(57.25)$ & $39.5(37.69)$ \\
Soft & $4.5(6.92)$ & $40.1(61.69)$ & $20.4(31.38)$ \\
t-value & $1.86^{\mathrm{NS}}$ & $2.99^{*}$ & $5.32{ }^{*}$ \\
NS: not significant; & "Significant $(p<0.05) ;$ & " & Highly sig- \\
nificant $(p<0.01)$ & & \\
\hline
\end{tabular}

Epicuticle

Ultrastructural observations on the epicuticle showed that in the normal hard-shelled, it is usually continuous. smooth-surfaced, with little or fine amorphous substance on the surface (Fig. 3). Tegumental gland pores and pore canals are distinctly observed on the surface of the epicuticle. The epicuticle actually consists of 2 distinct layers - a thin, electron-dense outer layer, about 0.44 to 
$0.62 \mu \mathrm{m}$ thick, and a thick inner layer, about 4.38 to $5.88 \mu \mathrm{m}$ thick (Fig. 4). This inner layer consists of horizontal lines with very fine fiber-like structures traversing vertically all throughout and is less electron-dense than the outer layer (Fig. 5). The epicuticle is not lamellated.

Soft-shelled prawns have a sometimes discontinuous epicuticle with densely or lightly distributed amorphous material on the surface (Fig. 6). Tegumental ducts and pore canals also pervade this layer although the latter structures are not so distinct on the surface. The epicuticle is often separated from the rest of the exoskeleton and also consists of an outer, thinner layer, about 0.4 to $0.55 \mu \mathrm{m}$ thick, and an inner, thicker layer, about 0.3 to $4.4 \mathrm{~m}$ thick. The horizontal lines and vertical fibers are not so distinct and crystal aggregates are often concentrated on theinner side of this inner layer, appearing to be in the form of spherulitic calcite islands (Fig. $7 \& 8$ ).

\section{Exocuticle}

The exocuticle is the thickest (57 to $62 \%$ of total exoskeleton thickness) among the cuticular layers in both hard- and soft-shelled prawns. In the hard-shell exocuticle, pore canals are shown as narrow tubules, 0.15 to $0.24 \mu \mathrm{m}$ in dia, running perpendicular to the surface of the cuticle (Fig. $9 \& 10$ ). The exocuticle consists of layers of chitin-protein fibers organized into lamellae (Fig. 10) which sometimes appear net-like (Fig. 11). The lamellae are widely-spaced, about 2 to 6.25 um wide. Mineralized crystals occur in the same orientation as the chitin-protein fibers, showing a distinct Bouligand pattern (Fig. 12). Calcitic spherules may also be observed in the non-lamellate region of the exocuticle.

In the soft-shell exocuticle, pore canals are of similar
Fig. 5. Penaeus monodon. Cross-section of epicuticle of hard-shelled prawn showing fine fibers traversing vertically through the thick inner layer (IL). EX: exocuticle. TEM; $8000 x$

Fig. 6. Penaeus monodon. Epicuticle of soft-shelled prawn showing densely distributed amorphous substance (AS) on surface. $T$ : tegumental gland pore. SEM; $22000 \times$
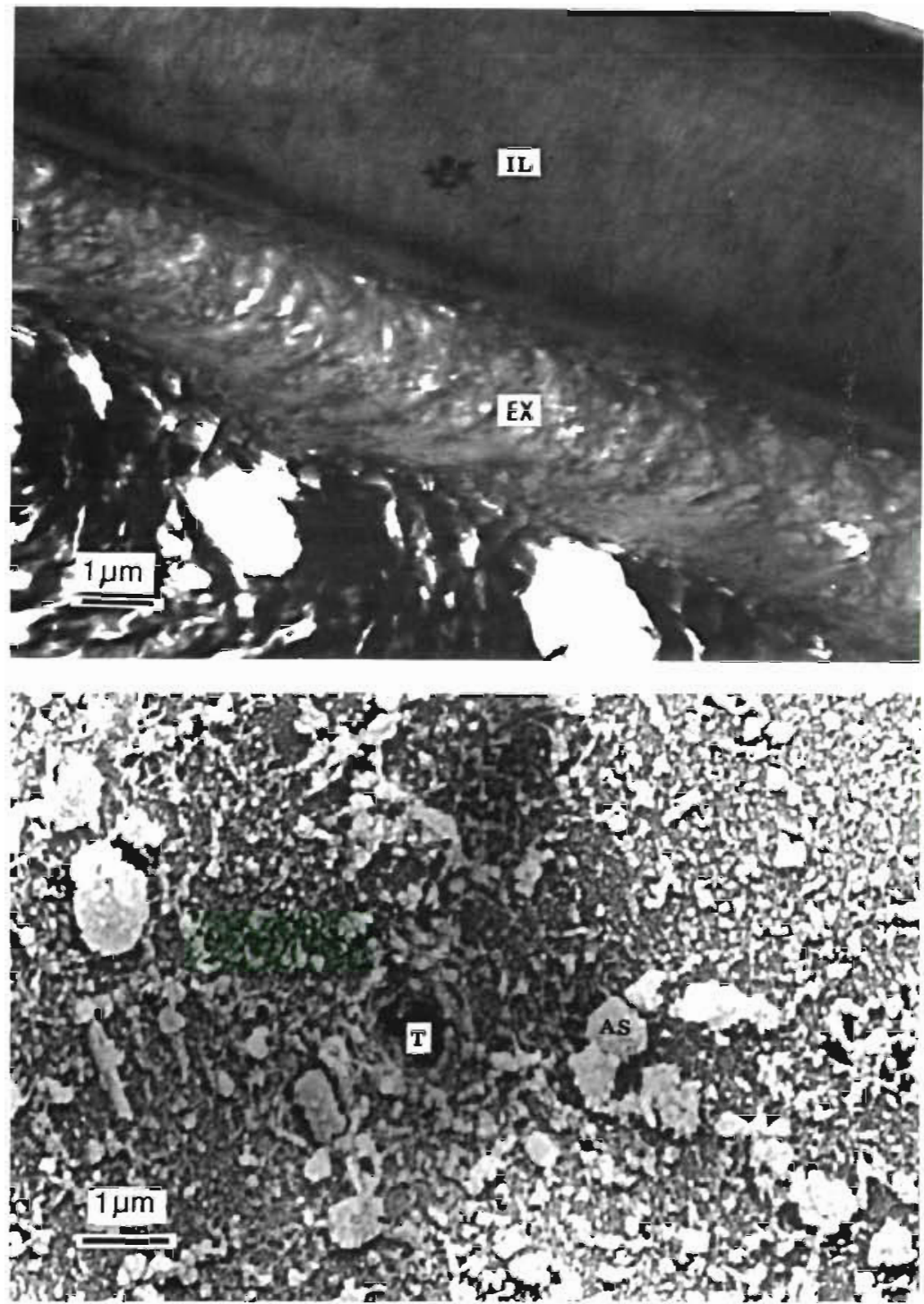


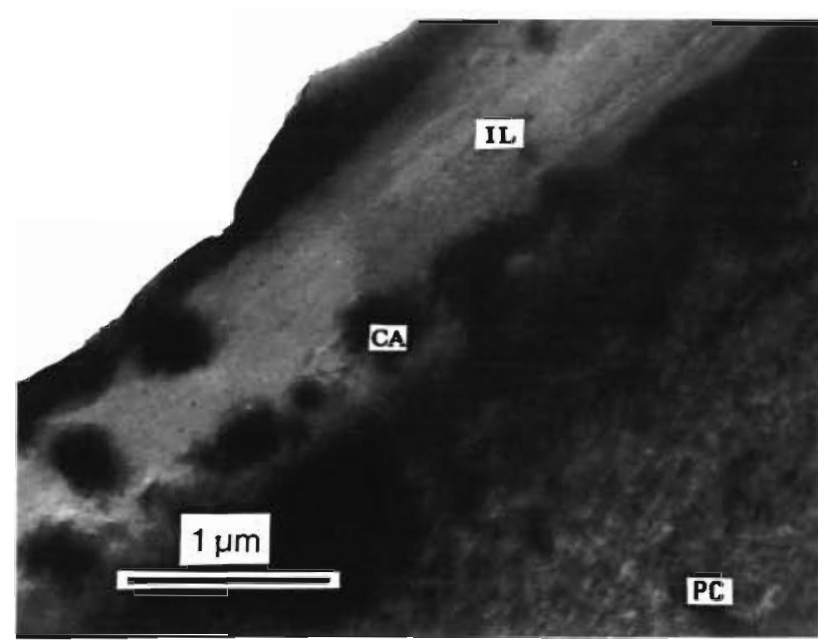

Fig. 7. Penaeus monodon. Damaged epicuticle of soft-shelled prawn. Note crystal aggregates (CA) concentrated on inner side of thick, inner layer (IL). PC: portion of pore canal on exocuticle. TEM; $20000 \times$

size $(0.18$ to $0.29 \mu \mathrm{m}$ dia.) and orientation as in the hard shell (Fig. 13). The chitin-protein fibers are fine and arranged in a not-so-distinct Bouligand pattern while the mineral deposits are not apparent (Fig. 14). The lamellar structure is also disrupted with the lamellae only about 1 um wide (Fig. 15).

\section{Endocuticle}

The endocuticle of the prawn has closely-spaced and finer lamellae which are about 0.24 to $1.88 \mu \mathrm{m}$ wide in the hard shell (Fig. 16) and 0.18 to $0.62 \mu \mathrm{m}$ in the soft shell (Fig. 17). There is a less compact arrangement of fibers in the hard shell endocuticle as compared with

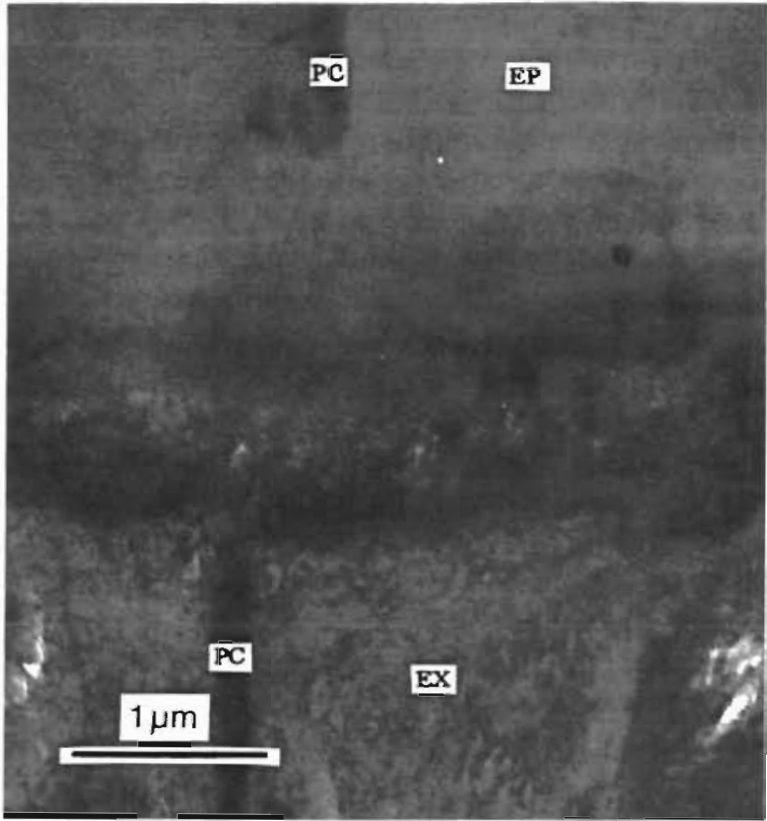

Fig. 9. Penaeus monodon. Eprcuticle-exocuticle junction of hard-shelled prawn. Note presence of pore canals (PC) running perpendicular to surface of exocuticle (EX). EP: epicuticle; TEM; $20000 \times$

the exocuticle (Fig. 18). Crystals in the soft shell endocuticle are in a disorderly pattern

\section{Membranous layer}

The innermost cuticular layer, the membranous layer, was clearly observed only in the hard shell. This layer is non-lamellate, very thin - about 0.38 to $0.67 \mu \mathrm{m}$ - with electron-dense rod-like structures running perpendicular to the layer, which could be portions of pore

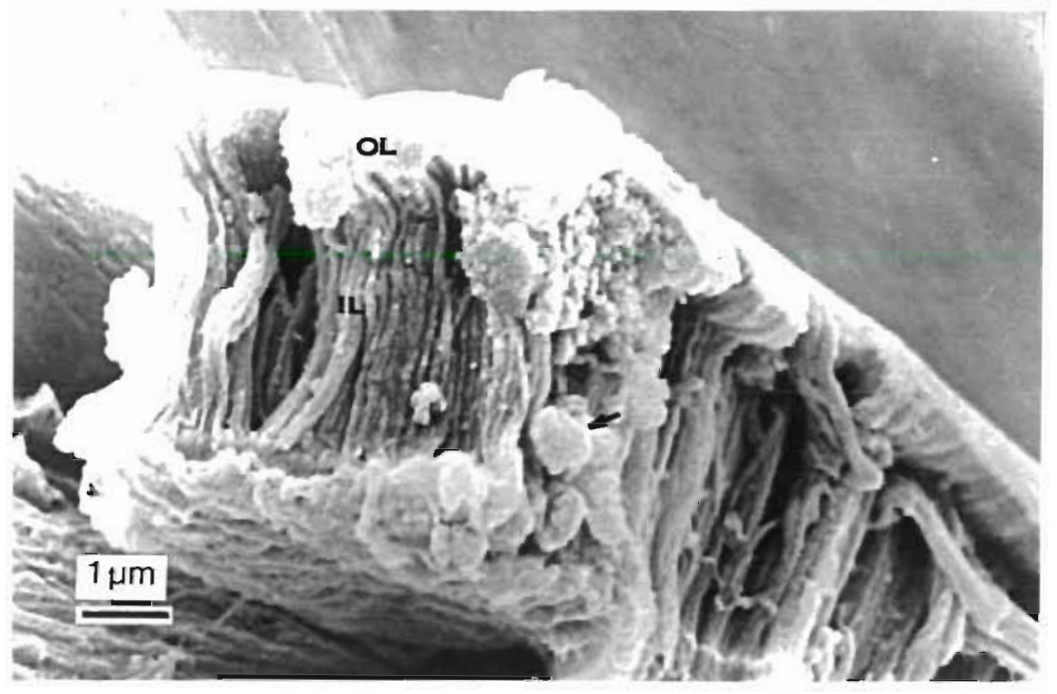

Fig. 8. Penaeus monodon. Epicuticle of soft-shelled prawn. Note vertical rod-like structures on inner layer (IL) of epicuticle and non-uniform distribution of crystals (arrows). OL: outer layer SEM; $20000 x$ 
Fig. 10. Penaeus monodon. Exocuticle lamellae (L) of hard-shelled prawn showing pore canal (arrow). Top of exocuticle is to right side of photo. SEM; $20000 \times$

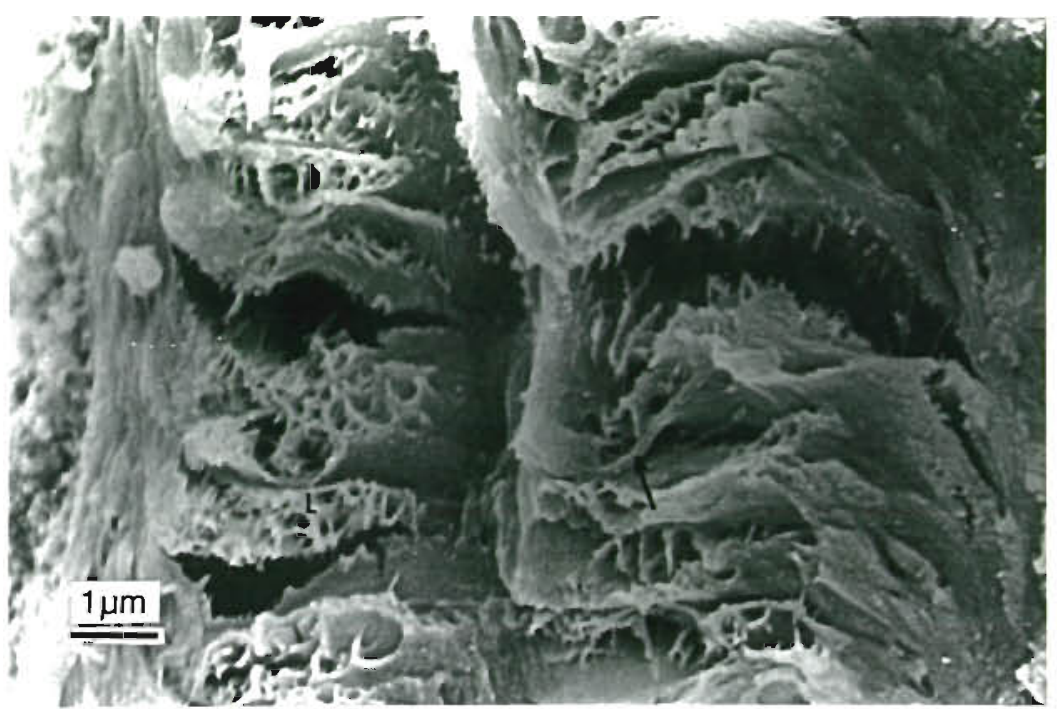

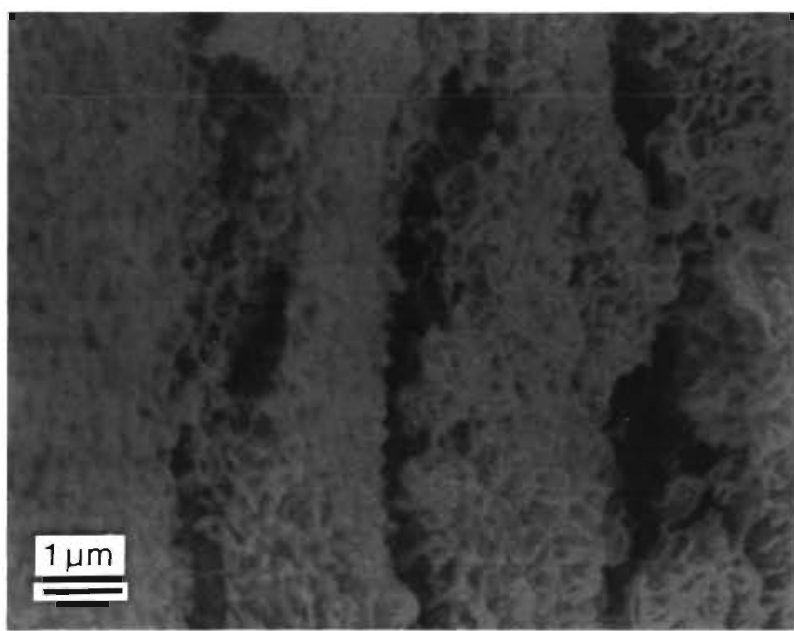

Fig. 11 Penaeus monodon. Net-like matrix of exocuticle of hard-shelled prawn. Top of exocuticle is to right side of photo SEVi; $20000 \times$

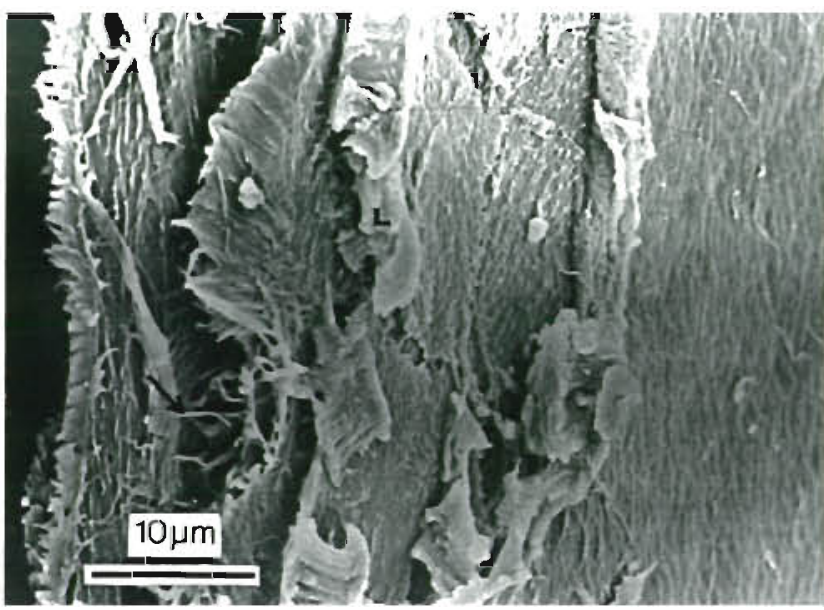

Fig. 13. Penaeus monodon. Exocuticle of soft-shelled prawn showing disrupted lamellae (L) and pore canals (arrow) running perpendicular to surface. Top of exocuticle is to right side of photo. SEM; $4000 x$
Fig. 12. Penaeus monodon. Exocuticle of hard-shelled prawn showing chitin-protein fibers and mineral crystals (C) in Bouligand pattern. TEM 20000

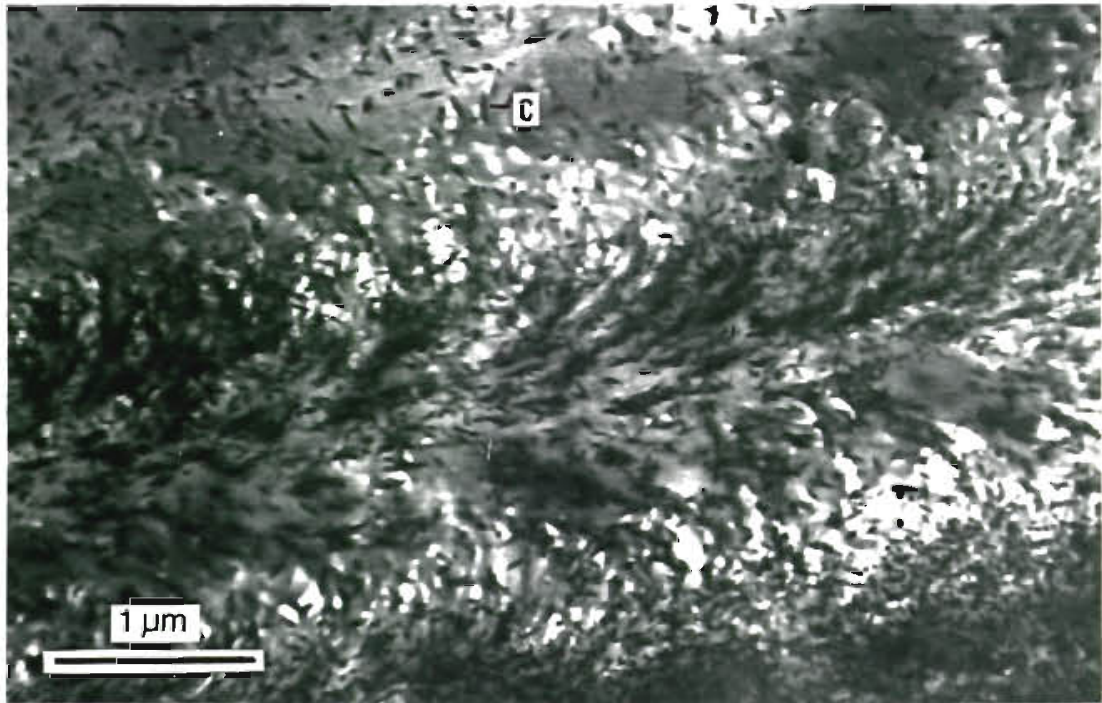




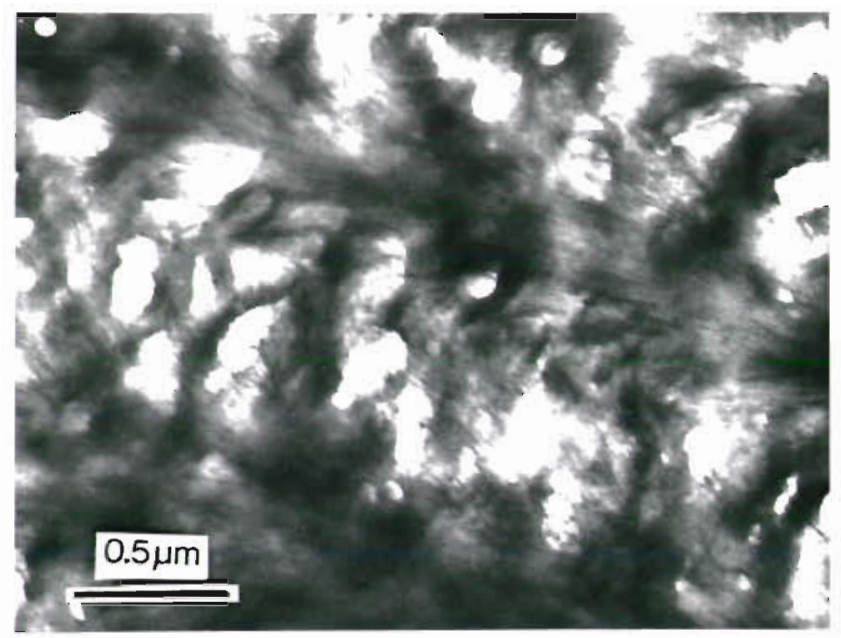

Fig. 14. Penaeus monodon. Fine chitin-protein fibers of softshelled prawn exocuticle. TEM; $30000 \times$

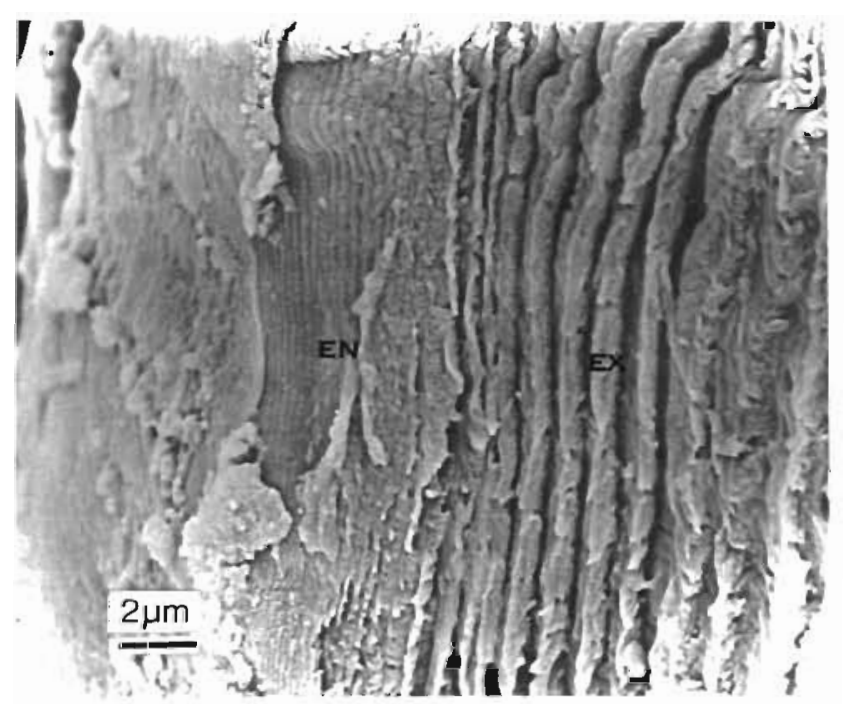

Fig. 15. Penaeus monodon. Lamellae of exocuticle (EX) of softshelled prawn. Note disrupted structure of lamellae. Top of exoskeleton is to right side of photo. EN: endocuticle. SEM; $8800 x$ canals (Fig. 19). The membranous layer of the soft shell is not so distinct (Fig. 20).

\section{Histopathology of the hepatopancreas}

In the hepatopancreas of hard-shelled prawns, Bcells or secretory cells are clearly observed in the epithelial tissue as enlarged cells with one large vacuole (Fig. 21 \& 23). Absorption cells (R-cells), the tall cells with numerous small vacuoles (which give them a 'foamy' appearance) and basal or central nucleus are also common. A few F- or fibrillar cells with a central nucleus are also found. The RI-cells (reserve inclusionbearing cells of Johnson 1980 or oval, vesicular reserve cells of Travis 1955) are numerous in the connective tissues surrounding the hepatopancreatic tubules.

The hepatopancreatic tubules of soft-shelled prawn are mostly disarranged and disrupted (Fig. 22 \& 24) while those of hard-shelled ones are generally wellarranged (Fig. 21). The lumen of the hepatopancreatic tubules appears larger because of the breakdown of secretory cells (arrows in Fig. 22 \& 24). The tubules appear compressed and, in some cases, are so disrupted that only the connective tissue capsules remain intact. Cell size and vacuolation of $\mathrm{R}$-cells are apparently reduced in soft-shelled prawns. RI-cells are indistinct in between the compressed hepatopancreatic tubules (Fig. 24).

\section{Electron probe microanalysis}

The elements detected by means of qualitative point analyses were $\mathrm{Ca}, \mathrm{P}, \mathrm{K}, \mathrm{Os}, \mathrm{Cl}, \mathrm{S}, \mathrm{As}$ and $\mathrm{Cu}$. The first 6 elements are shown in $\mathrm{x}$-ray traces of the exoskeleton samples in Fig. 25. There appeared to be no significant difference between hard-and soft-shell exocuticle as far as elemental composition is concerned. However,

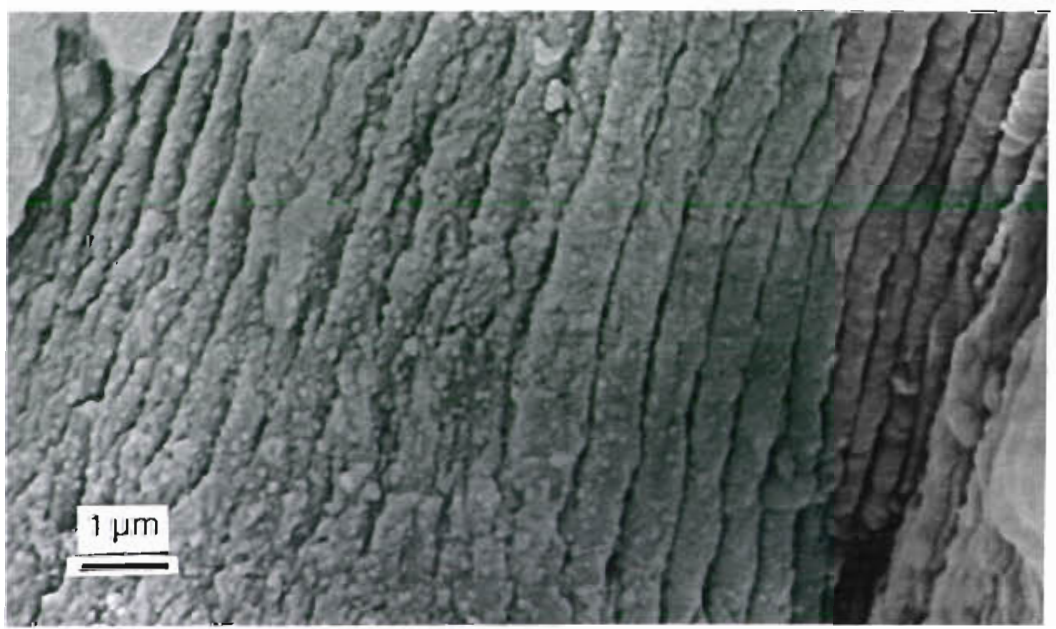

Fig. 16. Penaeus monodon. Lamellae of endocuticle of hard-shelled prawn. Top of endocuticle is to right of photo. SEM; $20000 \times$ 
Fig. 17. Penaeus monodon. Lamellae of endocuticle (EN) of soft-shelled prawn. Large, crystalline structures (arrows) could be extraneous substances. Top of exoskeleton is to right of photo. SEM $13200 x$

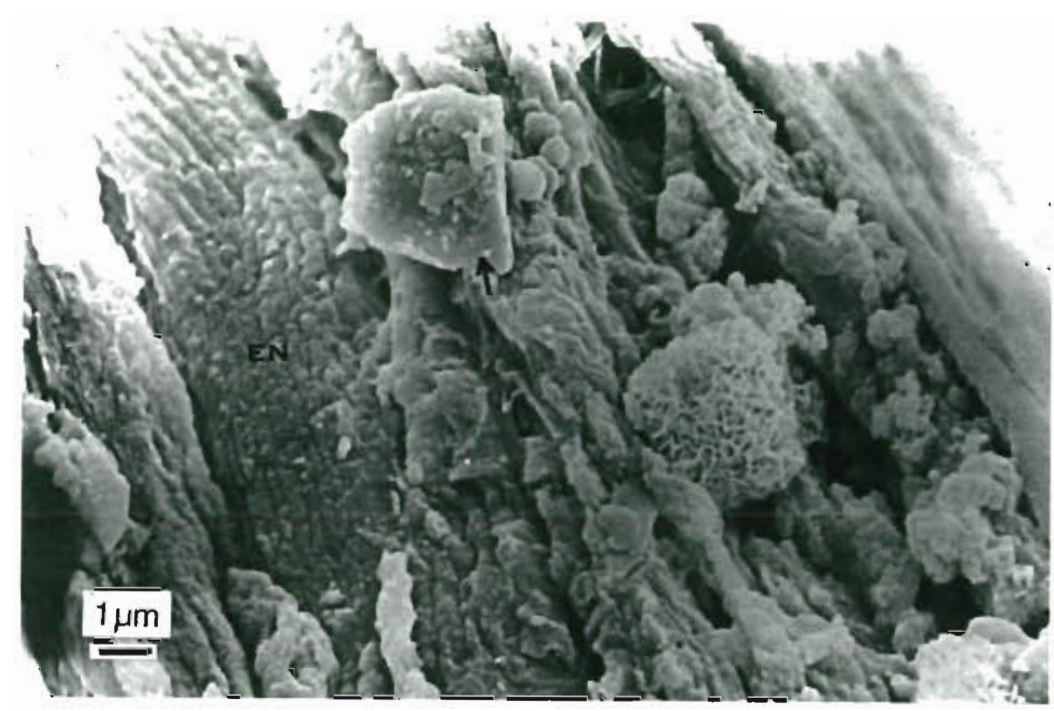

the soft-shell exocuticle exhibited lower peaks for the elements detected.

\section{Histochemical levels of calcium}

There appeared to be not much variation in the calcium content of hard and soft exoskeleton although the hard shell stained slightly more intensely. The hepatopancreas of soft-shelled prawn showed more prominent calcium staining than that of hard-shelled prawn.

\section{DISCUSSION}

\section{Histopathology of the exoskeleton}

The cuticular layers observed in this study were consistent with those described by Travis (1963) on the crustacean branchial exoskeleton, except that the membranous layer could not be distinguished from the rest using light microscopy. Moreover, instead of the endocuticle as the thickest layer of the crustacean exoskeleton (Travis 1963, Roer \& Dillaman 1984), the exocuticle was found to be the thickest layer in Penaeus monodon. The laminate pattern of the exoskeleton is due to the lamellar fiber system while the radial pattern is due to the pore canal system (Travis \& Friberg 1963).

The most conspicuous histopathological change in the soft shell is its significant thinness which, in addition to being soft, may have led to its greater susceptibility to mechanical damage. It is not surprising, therefore, to note that soft-shelled prawns are more prone to wounding and cannibalism (Baticados et al. 1986). The separation of the endocuticle from the exocuticle during sectioning has also been observed by Dall (1965) in Metapenaeus sp.

\section{Epicuticle}

The bilaminar and non-lamellate structure of the epicuticle (Dennell 1960, Travis 1963, Travis \& Friberg 1963, Dall 1965, Heghdahl et al. 1977 in Roer \& Dillaman 1984) was clearly revealed by means of transmission electron microscopy in the present work. The outer layer of the epicuticle is a thin surface membrane and is lipidrich (Richards 1951 in Dall 1965, Travis 1963) while the inner layer is protein-rich (Johnson 1980). The horizontal lines observed in the inner layer are probably artifacts. Mineralization appears to occur through the pore canal system (Travis 1963, Johnson 1980) which pervades the entire layer. Tegumental glands, also characteristic of the crustacean exoskeleton (Johnson 1980), are thought to be secretory in nature and open by pores onto the body surface (Leake 1975).

In the soft shell, the epicuticle is often separated from the rest of the exoskeleton but does not vary much in thickness from that in the hard shell. Mineralization appears to be disrupted or hampered by some mechanism, causing the crystals to form unevenly as spherulitic calcite islands on the inner side of the inner epicuticular layer, instead of being distributed homogeneously as in the hard shell.

\section{Exocuticle}

The exocuticle is the thickest layer in Penaeus monodon, a deviation from other reports on the crusta- 


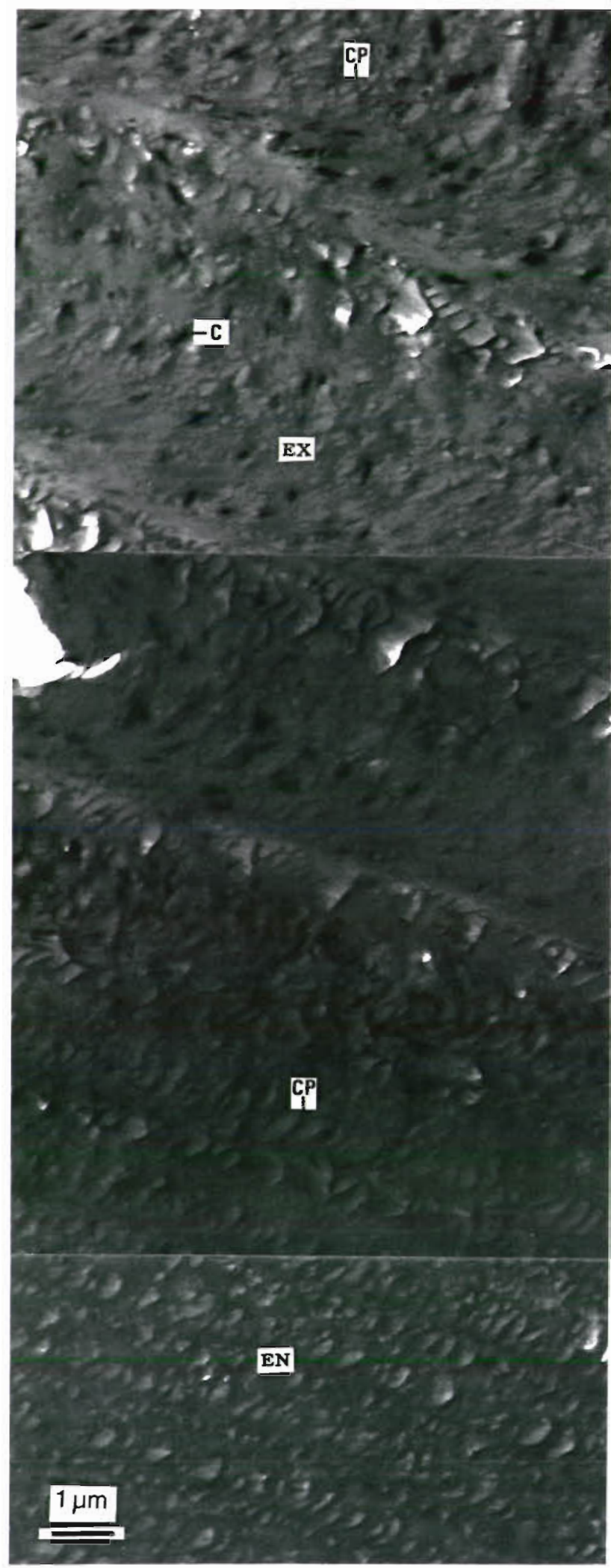

Fig. 18. Penaeus monodon. Exocuticle (EX) and endocuticle (EN) of hard-shelled prawn. Note loose arrangement of fibers (CP) in the lamellae of endocuticle as compared with those in exocuticle. C: mineral deposits. TEM; $8000 \times$ cean exoskeleton where the endocuticle was found to be the thickest (Travis 1955, 1963, 1965, Travis \& Friberg 1963, Roer \& Dillaman 1984). The exocuticle in the present work comprises about 57 to $62 \%$ of the total exoskeleton thickness, as also observed by Dall (1965) in Metapenaeus sp. wherein this layer comprised 52 to $55 \%$ of the exoskeleton thickness. This layer is composed of chitin-protein fibers (Richards 1951 in Dall 1965, Travis 1955) and acid mucopolysaccharides (Travis 1963) and is hardened by calcification and compounding of organic components (Travis 1955, 1965)

The more closely-spaced and disrupted lamellae as well as the generally thinner layer of the exocuticle of soft-shelled prawns could be an indication of incomplete or inhibited deposition of the layer. Consequently, the hardening that follows the formation of the basic structure may have been adversely affected also.

\section{Endocuticle}

As in other reports on the crustacean exoskeleton the endocuticle of Penaeus monodon has finer lamellae than the exocuticle (Dall 1965) and has crystal aggregates distributed along the lamellae (Roer \& Dillaman 1984). In contrast, Travis (1963) reported that the crustacean endocuticle has more widely spaced lamellae, an observation modified by Travis \& Friberg (1963) as true only in the outer endocuticle, but not in the inner endocuticle.

The finer lamellae and disorderly pattern of crystals in the soft-shell endocuticle as compared with those in the hard-shell endocuticle, likewise indicate disrupted formation and concomitant mineralization of this layer, as in the soft-shell exocuticle.

\section{Membranous layer}

This innermost layer of the exoskeleton is non-calcified (Travis 1955, 1963, Travis \& Friberg 1963) and in Macrobrachium rosenbergii, is formed only after calcification of the other layers is completed (Fieber 1982). This chitin-protein layer is $74 \%$ chitin in Cancer pagurus (Welinder 1979 in Roer and Dillaman 1984). The laminar pattern observed by other workers (Travis 1963, Travis \& Friberg 1963) was not observed in the present study. This layer is distinct only under TEM in the hard shell and not so in the soft shell. The electron-dense rod-like structures found in this layer must be portions of the pore canals through which protoplasmic extensions of the epidermis extend (Travis 1963) 
Fig. 19. Penaeus monodon. Membranous layer (bar) of cuticle of hard-shelled prawn. Pore canals (arrow) traverse vertically through this non-calcified layer. TEM; $10000 x$

Fig. 20. Penaeus monodon Membranous layer (arrow) of cuticle of soft-shelled prawn. TEM; $8000 \times$

Fig. 21. Penaeus monodon Section of the hepatopancreas of hard-shelled prawn showing well-arranged hepatopancreatic tubules. Note normal shape of lumen (L.). B: B- or secretory cell; $F$ : F- or fibrillar cell; R: R- or absorption cell; RI: reserve inclusion-bearing cell. Haematoxylin and eosin. $260 \times$
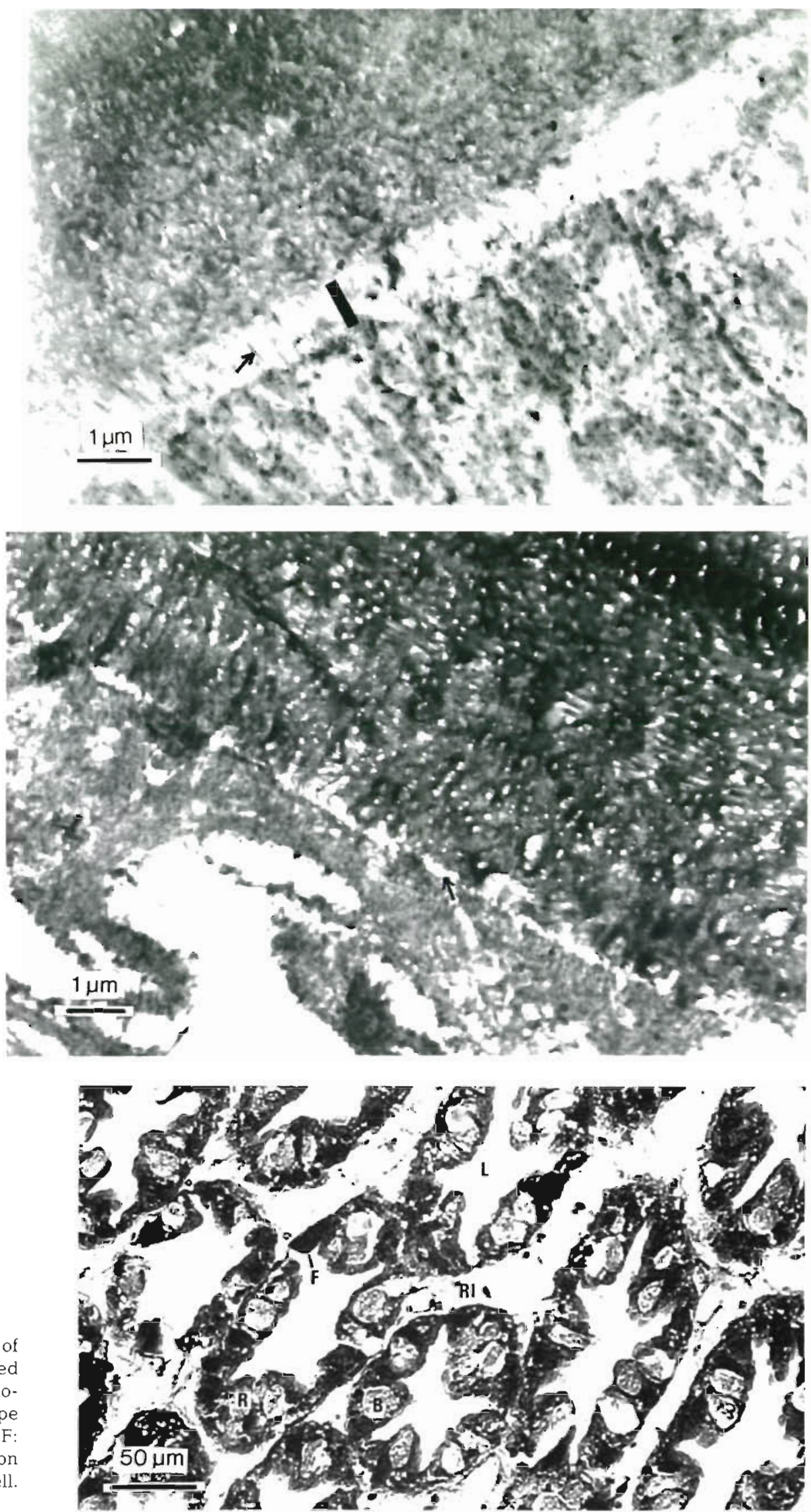

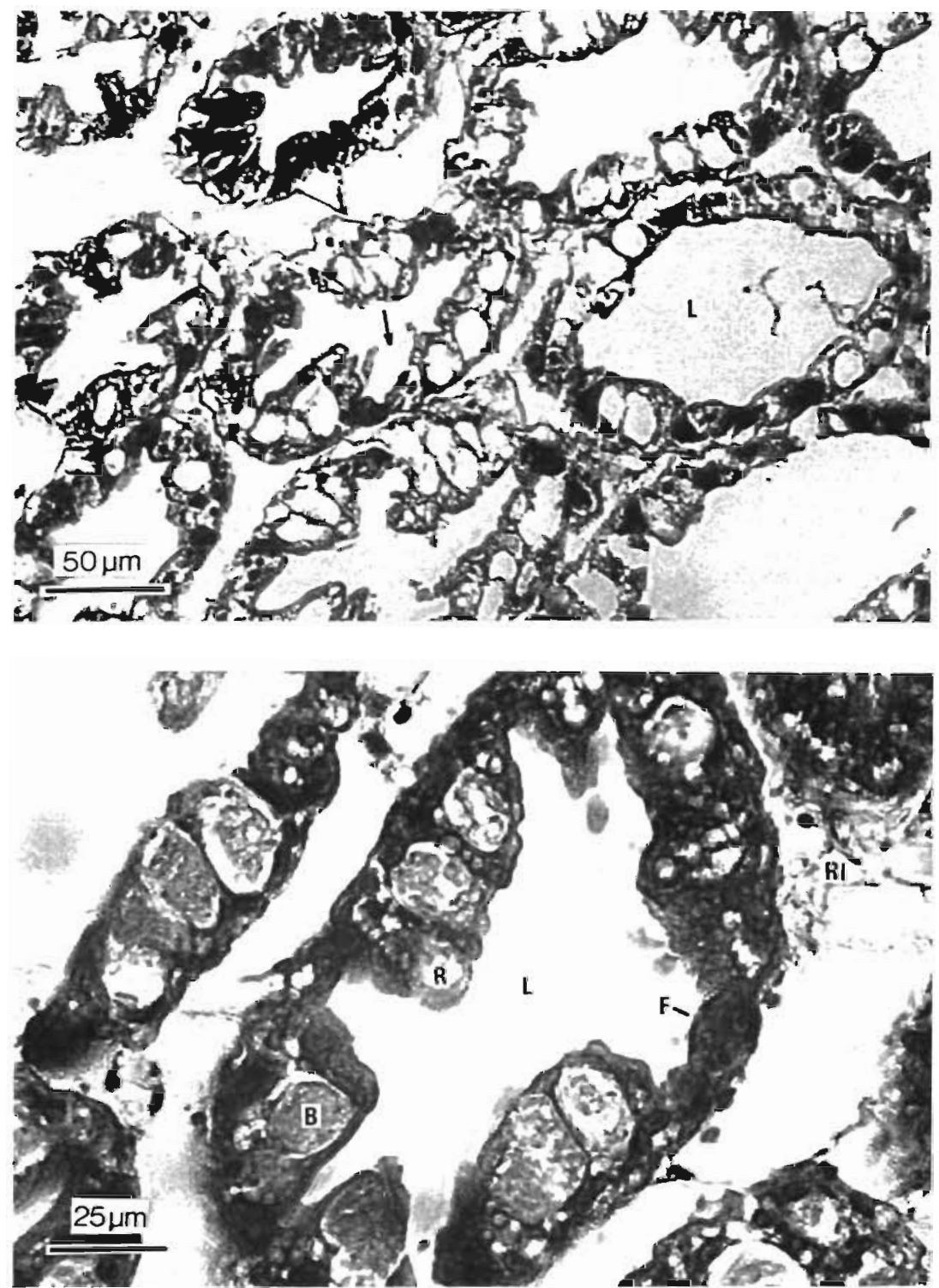

Fig. 22. Penaeus monodon. Section of the hepatopancreas of soft-shelled prawn showing disarranged and disrupted hepatopancreatic tubules. Arrow points to remains of secretory cell (B-ceil). L lumen of hepatopancreatic tubule. Haematoxylin and eosin. $260 x$
Fig. 23. Penaeus monodon. Hepatopancreatic tubule of hard-shelled prawn. B B- or secretory cell; F: F- or fibrillar cell L: Jumen; R- or absorption cell; RI: reserve inclusion-bearing cell. Haematoxylin and eosin. $520 x$
Histopathology of the hepatopancreas

The different types of cells found in the hepatopancreas vary in number according to the molting stage of the crustacean (Travis 1957). In the normal, hardshelled prawn, B-or secretory cells predominate. Many R-cells which function for absorption and food storage and a few F-cells which presumably produce digestive enzyme are found (Storch et al. 1982, Vogt 1985). Interstitial RI- or reserve cells are also numerous. These observations are characteristic of prawns in the intermolt stage, a period of active feeding (Travis 1955, 1957, Johnson 1980). It is also during this active feeding period that apocrine secretion of many secretory cells occurs. Travis (1955), working with the spiny lobster, reported apocrine secretion from B-cells. Apocrine se- cretion is the release of vacuole contents and adjacent cytoplasm into the lumen of hepatopancreatic tubules, leaving the basal portion and nucleus intact (Travis 1955). It is interesting to note that breakdown of secretory cells was observed in the soft-shelled prawn hepatopancreas which may have had something to do with impaired mechanisms in the processes of shell formation and hardening resulting in the inability of the soft-shelled prawn to molt and form a new hard exoskeleton. It may also be possible that once the softshelled prawns start to feed adequately, the epithelial cells of the hepatopancreas, particularly B-cells and Rcells, would assume their normal structure and function, thereby enabling the prawns to revert back to their hard-shell state.

Because of the general disruption of the hepatopan- 
Fig. 24. Penaeus monodon. Hepatopancreatic tubules of soft-shelled prawn. Arrow points to remains of secretory cell (B-cell): B: B-or secretory cell; F: For fibrillar cell; L: lumen; R: R- or absorption cell; RI: reserve inclusionbearing cell. Haematoxylin and eosin. $520 \times$

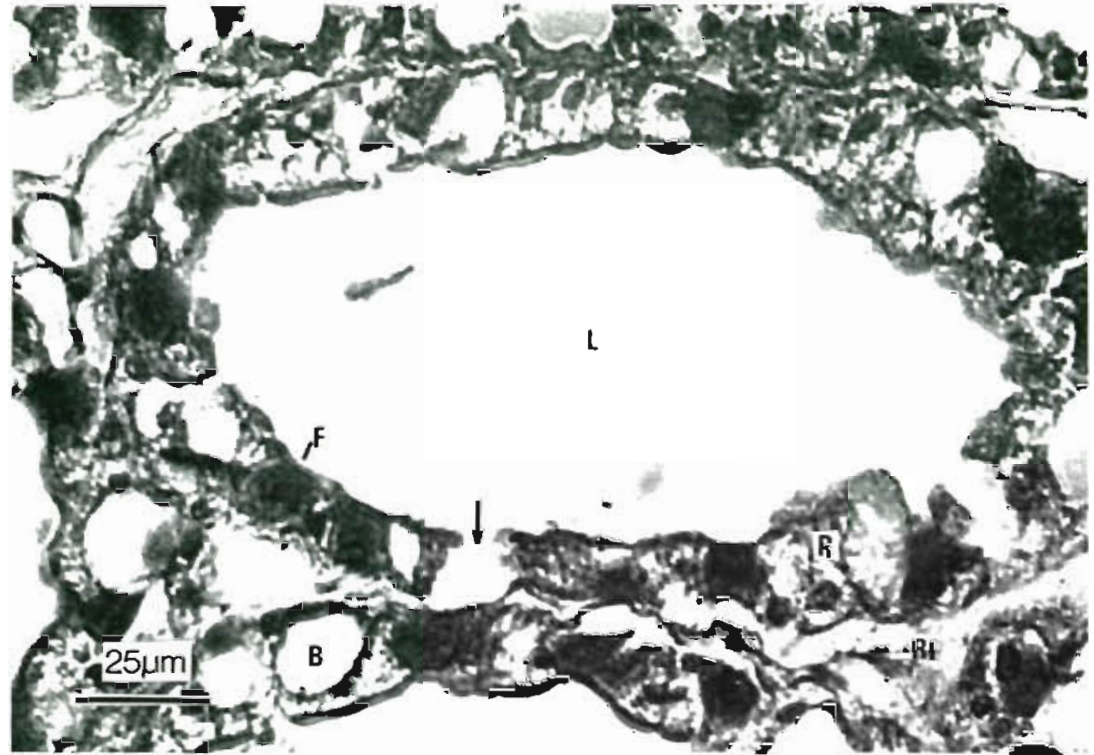

creatic tubules in the soft-shelled prawn hepatopancreas, the rest of the various cell types are barely recognizable. That sometimes only connective tissue capsules remain intact has also been observed by Pascual et al. (1983) in Penaeus monodon juveniles fed with $10 \%$ molasses as carbohydrate source in the diet. Decrease in the size of $\mathrm{R}$-cells was also reported by Storch et al. (1984) in $P$. monodon juveniles starved for 7 d, and by Vogt et al. (1985) in P. monodon postlarvae starved for more than $5 \mathrm{~d}$. A general increase in the number of cell organelles was observed by Vogt et al. (1985) in the hepatopancreas of $P$. monodon subjected to prolonged starvation and refed with certain diets. General atrophy of the hepatopancreatic cells, especially the absorption and secretory cells, has also been reported in the American lobster Homarus americanus after 4 d starvation (Rosemark et al. 1980).

Extensive vacuolation of $\mathrm{R}$-cells was also observed by Rosemark et al. (1980) in Artemia-fed American lobsters, the control group in their experiments. This 'foamy' appearance was attributed by earlier workers (Ham 1957 and Anderson 1957 in Rosemark et al. 1980) to the dissolution of glycogen during processing thereby leaving a pattern of open spaces in the liver cell cytoplasm. Penaeus monodon, however, does not store glycogen in the hepatopancreas (Vogt et al. 1985) and the 'foamy' vacuoles indicate the presence of lipid droplets in penaeids. Vogt et al. (1985) noted that the $P$. monodon hepatopancreas is lipid-oriented, and Schafer (1968) also observed that the pink shrimp $P$. duorarum has little glycogen in the hepatopancreas. Pascual et al. (1983) reported glycogen only from hepatopancreas of prawns fed $10 \%$ sucrose. The reduced vacuolation found in soft-shelled prawn R- cells may possibly result from the decrease of lipid droplets as also observed by Vogt et al. (1985) in $P$. monodon starved from 1 to $3 \mathrm{~d}$.

The reserve inclusion cells ('protein' cells of Cuenot 1893 in Johnson 1980, and oval reserve cells of Travis 1955) observed in between hepatopancreatic tubules are said to be present in all decapod crustaceans (Cuenot 1893 in Johnson 1980). They are believed to produce and store hemocyanin and materials for cuticle production which help sustain other tissues during stressful periods, e.g. starvation, disease and semihibernation in winter (Travis 1955, Johnson 1980). RIcells have been observed to diminish in size and number in starved crabs and those suffering from disease (Johnson 1980) presumably because the RIs are utilized to support other tissues which may be in need of oxygen, calcium, protein, etc. That soft-shelled prawns have indistinct RI-cells may be attributed to reduction in their quantity and size due to this stressful condition.

\section{Electron probe microanalysis}

The exoskeleton of the blue crab Callinectes sapidus, as a model for decapod crustaceans, is calcified not only with $\mathrm{CaCO}_{3}$, but also with $\mathrm{Ca}_{3}\left(\mathrm{PO}_{4}\right)_{2}$ and $\mathrm{CaSO}_{4}$ (Richards 1951 in Johnson 1980). The electron probe microanalysis of the exoskeleton of Penaeus monodon indeed showed $\mathrm{Ca}, \mathrm{P}$ and $\mathrm{S}$ to be among the elements present. It appears that calcium, in combination with phosphates, carbonates and sulfates, plays an important role in the mineralization and hardening of the prawn exoskeleton. This is supported by observations 
a
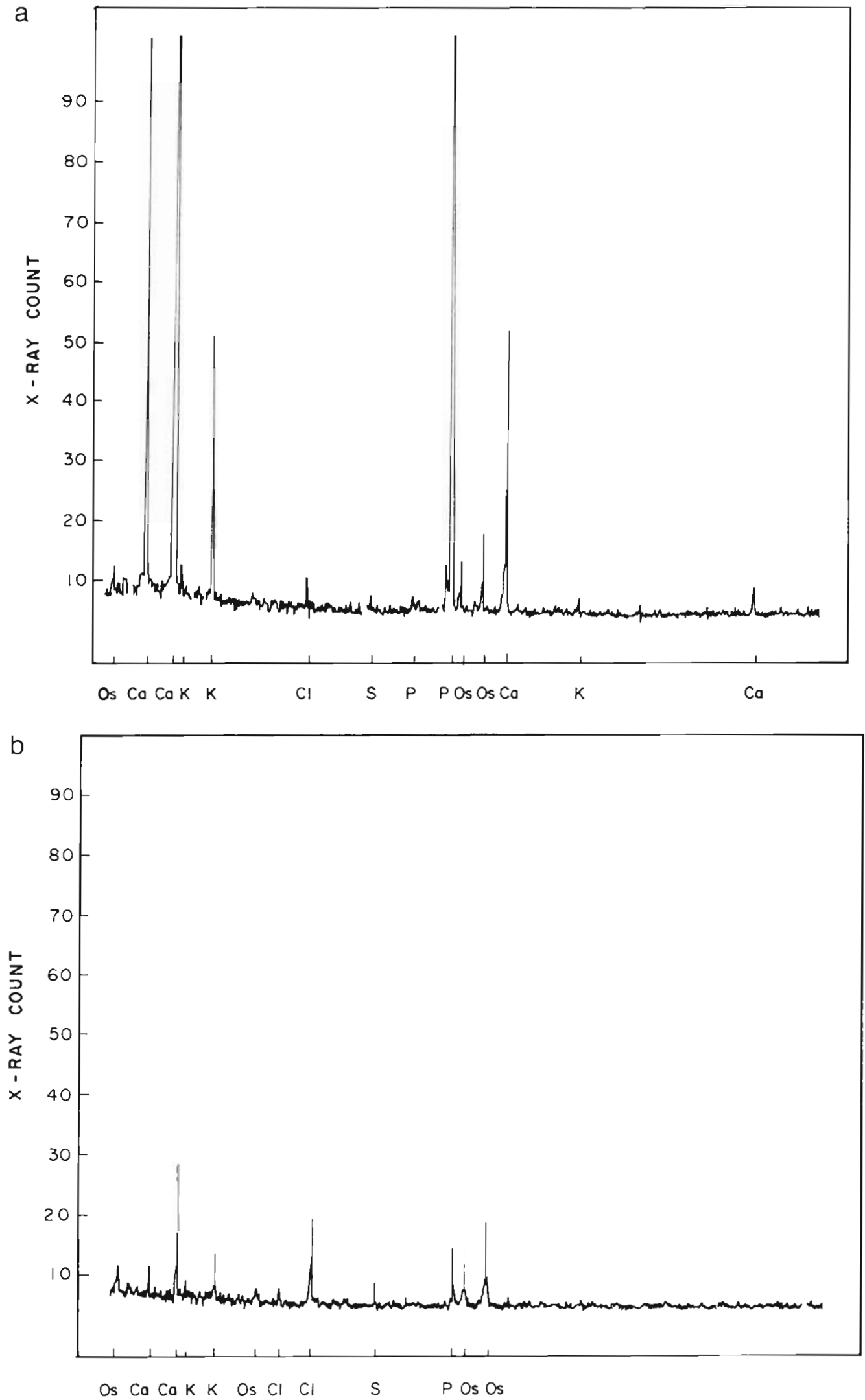

Fig. 25. Penaeus monodon. X-ray traces of (a) exocuticle from a hard-shelled prawn, and (b) exocuticle from a soft-shelled prawn, showing presence of calcium, phosphorus, potassium, osmium, chlorine, and sulfur 
of Arsenault et al. (1984) in the exact superpositioning of elemental $\mathrm{Ca}$ and $\mathrm{S}$ in the membrane-bounded vesicles of the epidermis and the presence of $P$ and $S$ in the remaining matrix of the vesicles.

The elemental composition of hard- and soft-shell exocuticle did not vary but it is possible that the difference may be in the concentration or concentration ratios of the elements detected as indicated by lower peaks of $\mathrm{Ca}$ in the soft shell samples. The presence of Os is due to osmium oxide, the post-fixative reagent used for electron microscopy while $\mathrm{Cu}$ is a component of the mounting medium used. The presence of As, however, could not be accounted for at this point.

\section{Histochemical levels of calcium}

The results of the histochemical analysis of calcium in the exoskeleton and hepatopancreas are supported by chemical analysis of calcium done on both tissues (Baticados et al. 1986). Cells of the hepatopancreas of soft-shelled prawn clearly showed greater calcium concentration than those of hard-shelled prawn hepatopancreas using the Alizarin Red S method. Calcium granules were well distributed in the cytoplasm of R-, $\mathrm{B}$ - and RI-cells, making them appear particularly reddish. Although the difference was insignificant, the soft exoskeleton nevertheless showed lower calcium content than the hard exoskeleton. Considering that the hepatopancreas is also a storage organ of organic and mineral reserves (Travis 1955), it appears that in the case of soft-shelled prawn, Ca reserves in the hepatopancreas (particularly in the R-, B-and RI-cells) have not been efficiently mobilized towards the exoskeleton where they are needed. The altered structure of the hepatopancreatic tubules in the soft-shelled prawn may have contributed to the incomplete or inhibited mobilization of $\mathrm{Ca}$ from the hepatopancreas to the exoskeleton. In addition, a comparison of the $\mathrm{Ca}$ concentrations in the hemolymph and residual tissues (muscles, others) between soft-shelled and hardshelled prawns by chemical analysis showed no significant difference (Baticados et al. 1986), indicating that the site of malfunction could be in the hepatopancreas.

The insignificant difference between the Ca concentrations of the soft and hard exoskeleton suggests that the limiting factor in the formation of a hard shell may not be calcium alone. Previous chemical studies showed that there is a significantly higher concentration of phosphorus in the hard exoskeleton and softshelled prawn hepatopancreas than in the soft exoskeleton and hard-shelled prawn hepatopancreas, respectively (Baticados et al. 1986). Moreover, the present study revealed ultrastructural differences between the soft and hard shell, including changes in crystal formation and arrangement. This study further supports the view that the hepatopancreas serves as the major reservoir for these elements (Travis 1955, 1957, Storch et al. 1982).

Since the hepatopancreas is the digestive gland of the prawn and serves as the major storage organ as well of substances needed for the hardening of the exoskeleton, attention must be paid to the nutritive value of the food given to the prawn, in order to help surmount the problem of soft-shelling. Fieber (1982) reported that some crustacean species are calcified from reserves in the hemolymph and hepatopancreas. Demobilization of storage material in hepatopancreatic cells was observed by Vogt et al. (1985) in starved Penaeus monodon. The current work supports the view that adequate nutrition may prevent the occurrence of soft-shelling in prawns. Reversal of soft-shelling has, in fact, been accomplished by feeding prawns with adequate quantities of mussel meat, an excellent food for P. monodon (Baticados et al. 1986). It would be interesting to find out how various $\mathrm{Ca} / \mathrm{P}$ ratios in the diet would affect the shell quality of the prawns.

Acknowledgements. The authors thank Ms Margarita C de la Cruz and Ms Susan Torrento for histological work, and Dr Alcestis $\mathrm{T}$ Llobrera for critical review of the manuscript.

\section{LITERATURE CITED}

Arsenault, A. L., Castell, J D., Ottensmeyer, F. P. (1984). The dynamics of exoskeletal-epidermal structure during molt in juvenile lobster by electron microscopy and electron spectroscopic imaging. Tissue Cell 16: 93-106

Baticados, M. C. L., Coloso, R. M., Duremdez, R. C. (1986). Studies on the chronic soft-shell syndrome in the tiger prawn, Penaeus monodon Fabricius, from brackishwater ponds. Aquaculture 56: 271-285

Dall, W. (1965). Studies on the physiology of a shrimp, Metapenaeus sp. Crustacea: Decapoda: Penaeidae. Aust. J. mar. Freshwat. Res. 16: 13-23

Dennell, R. (1960). Integument and exoskeleton. In: Waterman, $\mathrm{T} H$. (ed.) The physiology of Crustacea, Vol. 1. Academic Press, New York, p. 449-472

Dillaman, R. M., Roer, R. D. (1980). Carapace repair in the green crab, Carcinus maenas (L.). J. Morph. 163: 135-155

Fieber, L. A. (1982). Ion metabolism during molting in the freshwater prawn, Macrobrachium rosenbergii. M. S. thesis, Univ. of Miami, Coral Gables

Humason, G. L. (1972). Animal tissue techniques, 3rd edn. W. H. Freeman, San Francisco

Johnson, P. T (1980). Histology of the blue crab, Callinectes sapidus. Praeger Publishers, New York

Leake, L. (1975). Comparative histology. Academic Press, London

Pascual, F. P., Coloso, R. M., Tamse, C. T. (1983). Survival and some histological changes in Penaeus monodon Fabricius juveniles fed various carbohydrates. Aquaculture 31: $169-180$ 
Roer, R. D., Dillaman, R. M. (1984). The structure and calcification of the crustacean cuticle. Am. Zool. 24: 893-909

Rosemark, R., Boswer, P. R., Baum, N. (1980). Histological observations on the hepatopancreas in juvenile lobsters subjected to dietary stress. Proc. World Maricult. Soc. 11 $471-478$

Schafer, H. J. (1968). Storage materials utilized by starved pink shrimp, Penaeus duorarum Burkenroad. FAO Fish Rep. 57.393-403

Storch, V., Janssen, H. H., Cases, E. (1982). The effects of starvation on the hepatopancreas of the coconut crab, Birgus latro (L.) (Crustacea, Decapoda). Zool. Anz. 208: 115-123

Storch, V., Juario, J. V., Pascual, F. P. (1984). Early effects of nutritional stress on the liver of milkfish, Chanos chanos (Forsskal), and on the hepatopancreas of the tiger prawn, Penaeus monodon (Fabricius). Aquaculture 36: 229-236

Travis, D. F. (1955). The molting cycle of the spiny lobster, Panulirus argus Latreille. U. Pre-ecdysial histological and histochemical changes in the hepatopancreas and integumental tissues. Biol. Bull. mar. biol. Lab., Woods Hole 108: $88-112$

Travis, D. F. (1957). The molting cycle of the spiny lobster, Panulirus argus Latreille. IV. Post-ecdysial histological and histochemical changes in the hepatopancreas and integumental tissues. Biol. Bull. mar. biol. Lab., Woods Hole 113: $451-479$
Travis. D. F. (1960). The deposition of skeletal structures in the Crustacea. I. The histology of the gastrolith skeletal tissue complex and the gastrolith in the crayfish, Orconectes (Combarus) virilis Hagen-Decapoda. Biol. Bull. mar. biol. Lab., Woods Hole 118: 137-149

Travis, D. F. (1963). Structural features of mineralization from tissue to macromolecular levels of organization in the decapod Crustacea. Ann. N.Y. Acad. Sci. 109: 177-245

Travis, D. F. (1965). The deposition of skeletal structures in the Crustacea. V The histomorphological and histochemical changes associated with the development and calcification of the branchial exoskeleton in the crayfish, Orconectes virilis Hagen. Acta Histochem. 20: 193-222

Travis, D. F., Friberg, U. (1963). The deposition of skeletal structures in the Crustacea. VI. Microradiographic studies of the exoskeleton of the crayfish Orconectes virilis Hagen. J. Ultrastruct. Res. 9: 285-301

Vogt, G. (1985). Histologie und Cytologie der Mitteldarmdrüse von Penaeus monodon (Decapoda). Zool. Anz. 215: $61-80$

Vogt, G., Storch, V., Quinitio, E. T., Pascual, F. P. (1985). Midgut gland as monitor organ for the nutritional value of diets in Penaeus monodon (Decapoda). Aquaculture 48: $1-12$

Yano, I. (1975). An electron microscope study on the calcification of the exoskeleton in a shore crab. Bull. Jap. Soc. scient. Fish. 41: 1079-1082 